\title{
Article
}

\section{Compliance with International Norms: Implementing OECD DAC Principles in South Korea}

\author{
Lim, Sojin
}

Available at http://clok.uclan.ac.uk/17576/

Lim, Sojin ORCID: 0000-0003-1395-7672 (2014) Compliance with International Norms: Implementing OECD DAC Principles in South Korea. Globalizations, 11 (6). pp. 859-874. ISSN 1474-7731

It is advisable to refer to the publisher's version if you intend to cite from the work. http://dx.doi.org/10.1080/14747731.2014.904158

For more information about UCLan's research in this area go to http://www.uclan.ac.uk/researchgroups/ and search for < name of research Group>.

For information about Research generally at UCLan please go to http://www.uclan.ac.uk/research/

All outputs in CLoK are protected by Intellectual Property Rights law, including Copyright law. Copyright, IPR and Moral Rights for the works on this site are retained by the individual authors and/or other copyright owners. Terms and conditions for use of this material are defined in the policies page.

\section{CLoK}

Central Lancashire online Knowledge www.clok.uclan.ac.uk

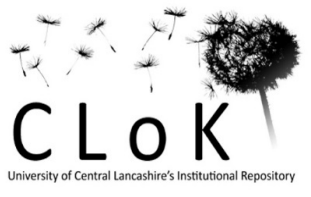




\title{
Compliance with International Norms: Implementing OECD DAC Principles in South Korea
}

\author{
Sojin Lim
}

\begin{abstract}
This study raises the question of what determines compliance with the OECD DAC framework on the basis of a case study of South Korea. This research argues that fragmented institutional structures limit the bureaucratic capacity for greater compliance. At the same time, the findings illustrate that lack of interest from dominant institutions can limit the consolidation of political will for change at the national level. This study has implications for future DAC donors in that special and peer reviews can be useful methodologies to identify current limitations for change. Finally, the study emphasises the importance of consolidated political will in terms of readiness to adopt global standards at the domestic level before commencing membership and obligatory processes.
\end{abstract}

Keywords: Global Norms, OECD DAC, Compliance, Peer Review, Domestic Politics, Institutional System, Aid Effectiveness, South Korea

\section{Introduction}

Schools of international soft law have widely argued that international norms can achieve a higher level of implementation than domestic laws (for example, see Paulo and Reisen, 2010; Schäfer, 2006), and that peer review can be a flexible tool in adopting best practices in order to comply with these norms (OECD, 2007b; Pagani, 2002, p. 15). The peer review, defined as 'the systematic examination and assessment of the performance of a state by other states', is known to be an effective compliance instrument in terms of implementing international frameworks, or soft laws, for member states. As such, peer review is a process of persuading member countries to implement standards and principles through the peer pressure exerted during the review process (Pagani, 2002; Paulo and Reisen, 2010). At the same time, as the peer review findings are made public, public scrutiny can influence a country's behavioural change towards compliance with international norms (UNECA, 2002). The term 'compliance' 
used in this study thus refers to the adoption of and conformity to internationally agreed norms, standards and principles.

Most international organisations have operated peer review systems amongst their member states. The World Trade Organisation (WTO), for example, uses a 'trade policy review mechanism' as a peer review tool for the purpose of monitoring trade policy and for the implementation of agreed principles by member countries (Pagani, 2002). Generally, international organisations conduct the peer review through three main phases, namely the preparatory, consultation and assessment phases, although some of them utilise a more complex process (UNECA, 2002). Just as international soft law is not a binding act, peer review likewise does not require judicial judgment. It is more common for peer review to be process of open dialogue aimed at encouraging the country under review to improve its compliance through adopting policies or best practices, standards or principles (Pagani, 2002). Trubek and Trubek (2005) argue that international bodies tend to provide guidelines for compliance rather than uniform rules, and that member states have a degree of freedom in achieving agreed objectives under soft law. As a result, member countries tend to design their own timetables and methods of implementation, which can cause them to lag behind in terms of compliance performance (Trubek and Trubek, 2005).

It does not seem, therefore, that member countries always comply with international standards and principles even though they abide by the peer review process. Especially in the case of the Organisation for Economic Co-operation and Development (OECD) Development Assistance Committee (DAC), even though member states are obliged to undergo peer review, the implementation level of DAC standards such as the Paris Declaration (PD), the Accra Agenda for Action (AAA) and the Global Partnership for Effective Development Cooperation is not always high across member states. When the OECD DAC peer review examiners assessed countries' aid delivery mechanisms and management structures, they found that DAC member donors showed different levels of responsiveness to OECD standards (De Renzio, 2008; OECD, 2011a). According to the PD monitoring surveys, out of the 23 donor countries that signed the PD, no country fully met all its targets, thereby making the overall performance level rather disappointing. However, the donors' performances vary: Denmark, Sweden and the United Kingdom (UK) showed higher levels of accomplishment, having achieved more than four or five PD indicators, while Japan, South Korea (hereinafter, Korea), Switzerland, the United States (US) and Turkey, only met one or two of the indicators (OECD, 2011a).

Why then do some countries show lower implementation levels while others comply more fully with the agreed norms? What are the main causes of their failure to comply? Is it because peer pressure does not provide uniform rules but only recommendations, as Trubeck and Trubeck (2005) have suggested? Scholars such as Mahon and McBride (2009) argue that the OECD peer review recommendations are less powerful in terms of enforcement of standards in comparison with other international institutions such as the International Monetary Fund (IMF), the WTO and the World Bank. However, there is no obvious common denominator that fully explains the ties between non-compliance and the power of the international institutions. At the same time, Paulo and Reisen (2010) claim that failure to comply is precisely due to the fact that current international standards, especially those of the OECD DAC, are developed by traditional donors and that the peer review mechanism does not fully integrate emerging countries. However, this does not explain the cases of Japan, Switzerland and the US, whose level of compliance with PD targets were low even though they are considered to be traditional DAC donors. It seems then that it is the similar administrative arrangements and institutional structures of the European Union (EU) countries, rather than "DAC-ability" per se, which determines levels of compliance with DAC norms (Kim and Lightfoot, 2011; Rowlands, 2008). 
With these issues in mind, this study aims to examine why some governments are reluctant to adopt and conform to the global norms within the OECD DAC framework, despite their membership obligations and the role of peer pressure. It employs Korea as a case study not only because it is a new DAC member but also because it is a non-EU member state. Korea has been regarded as having DAC-ability as a result of achieving DAC membership in 2010, but its administrative arrangements and institutional structures are different to that of EU member states. As noted above, non-EU countries do not appear to conform to OECD DAC principles such as those contained in the PD and the final monitoring survey result demonstrated that countries like the UK, Sweden and Denmark show higher levels of implementation compared to non-EU countries such as the US, Japan and Korea (see OECD, 2011a). However, Korea shares much in common with other non-European countries in that its aid systems is relatively diffuse and uncoordinated in comparison to those of so-called traditional European DAC members (Kim and Lightfoot, 2011; Rowlands, 2008). On top of that, most case studies of non-compliant countries have focused on traditional donors, but we have as yet relatively little understanding of whether theories built upon the European experience are commensurate with non-European cases such as Korea.

In doing so, this paper begins by reviewing the existing compliance literature as there have been relatively few attempts to explain different levels of compliance through the peer review mechanism. The third section elaborates the research methodology used in the study, including the research propositions drawn from compliance theories and the methods used for data collection. As existing compliance theories are mostly based upon European cases and compliance around EU directives, the fourth section in this paper examines whether the propositions are consistent with OECD principles given that non-European countries are also members. The study then analyses the Korea's behavioural change with regards to OECD standards and assesses whether the Korean case is consistent with the research propositions, or whether there are different variables that can explain Korea's low compliance levels by looking at the peer review processes and their results. Finally, the study concludes with a summary of the findings and discusses their implications for future non-European candidates for DAC membership.

\section{Compliance with International Normative Frameworks}

Scholars have debated the reasons why states comply, or do not comply, with international standards and principles, and have proposed a number of factors which may determine different levels of compliance. Early compliance theorists predominantly argued that some countries tend to comply with global norms due to enforcement mechanisms such as sanctions, while others scholars have relied more on procedural mechanisms of system management in explaining change. These competing arguments are known as enforcement and management models respectively (Tallberg, 2002). More recently, these two approaches have been reinterpreted combining strategic choice theory with an enforcement model, and administrative constraints and national capacity theories with a managerial model (see Linos, 2003). In the former, the definition of enforcement focuses more on national preferences than power games between countries while others generally understand the enforcement mechanism in terms of sanctions (Börzel et al., 2010; Donno, 2010; Linos, 2003). In comparison, scholars such as Mbaye (2001) argue that factors influencing compliance include administrative constraints, strategic choice, institutional design and elite learning, multi-level governance and public opinion. Others, such as Chayes and Chayes (1993), argue that lack of behavioural change towards greater compliance is a result of three circumstances: the ambiguity of international 
law; the national capacity to adopt international norms; and the temporal dimension of changes. In addition, it has also been implied that domestic efforts can be a main determinant of compliance (UNECA, 2002).

However, these variables, dealt with separately by various scholars, are in reality to be interlinked. For example, while Mbaye (2001) emphasises that administrative constraints imply a lack of national capacity, Chayes and Chayes (1993) emphasise national capacity as a dominant factor. With similarities to Mbaye (2001), Tallberg (2002) discusses limitations in national capacity while explaining the role of domestic system management. Börzel et al. (2010) have re-categorised those elements into different groups, such as enforcement, capacity and legitimacy. However, in some cases, it is unclear whether the non-compliance of particular state is a result of that state's choice or lack of capacity (Donno, 2010). This, in turn, implies that mixed approaches need be applied when explaining the countries' varying degrees of responsiveness to international agreements. With this in mind, this study attempts to synthesise the variables highlighted by the existing compliance literature into international and domestic frameworks.

\section{International and Domestic Variables}

As is conventionally believed, membership of international institutions influences national policies. As states obtain member status of an international organisation which has the "same policy preferences' as national policies, it is easier for them to conform to international agreements than non-member states (Haas, 2008; Holzinger et al., 2008). In light of this, states' decisions can also be influenced by international institutions, where institutions are defined as 'persistent and connected sets of rules that prescribe behavioural roles, constrain activity and shape expectations' (Haas, 2008, p. 24), and these rules are the product of agreements by member states (Glodmann, 2012). However, this does not mean that member states always comply with the international laws induced by the organisation, as identical policy preferences do not mean identical domestic policies. In other words, there is still a high possibility of laggards despite similar notions of policies between supranational and national laws (for example, see Holzinger et al., 2008). This indicates the possibility of conflict between international standards and national interests (Abbott and Snidal, 2000). While national law reflects national interests, international law rather reflects the collective interests of member states. According to Goldmann (2012), it is highly likely that states distinguish international from national law, and they seem to differentiate between soft law and non-soft law within international law. Why then do some members have a greater tendency to comply with international principles when these global principles are not legally binding and do not fully reflect national interests? This can be explained in the 'design of international principles' by leading members of the international institutions (Paulo and Reisen, 2010). During the negotiation process, states tend to bargain close to their own national interests in designing standards and principles (Mbaye, 2001), and thus, the likelihood of dominance of key leaders within the broader membership becomes relatively high (Putman, 1988).

Furthermore, there is a broad consensus that the domestic politics and objectives of the states have a strong relation with compliance. As argued above, international law is the product of mutual consent by states, whilst national law reflects state interests. Similarly, according to Haas (2008), signatories decide whether to comply with international agreements through their political calculations and national interests. Besides, even though they may have agreed to the international standards, a state's decision at home relies on the country's interests and preferences (Linos, 2003; Stiles and Thayne, 2006; Tarp, 2000). As such, divergent interests among different domestic coalition partners can impact levels of implementation through 
national policies (Hass, 1998; Mbaye, 2001). In other words, international norms are 'located in the twilight between law and politics' (Skjaerseth et al., 2006). At the same time, it has been argued that a lack of political will in the domestic system can limit response efficiency regarding the international requirements. As mentioned at the beginning of this study, the case of the PD signatories, whereby many members been reluctant implement PD norms, supports this argument (OECD, 2008b). Lack of political will can stem from divergent interests across domestic institutions, not only because they differentiate multiple laws on the basis of their own values, but also because they choose to comply with the specific laws under which they can achieve their ends (Abbott and Snidal, 2000; Goldmann, 2012). Differing objectives for each institution at the national level hinders the establishment of a consolidated political will to conform to the international law. This, in turn, is linked to the issue of actors within the domestic arena, which will be discussed later in this section.

While state choice theory argues that countries decide their level of compliance based on their national interests and political calculations, it also implies the importance of political manoeuvring between institutions as a result of their conflicting interests and objectives. In comparison, state capability theory tends to emphasise the role of governmental administrative capacity in determining the degree of compliance as it illustrates why countries may have difficulties in implementing international agreements at home (for example, Mbaye, 2001). It is evident that states are not always capable of observing international standards even if they wish to do so (Haas, 2008). This is likely when national bureaucracies have low ability to adopt international norms to their domestic processes (Mbaye, 2001; Linos, 2003). In other words, a weak government bureaucracy can interrupt the implementation process, leading to a systemic delay. In the case of EU members, it has been argued that state structures, including 'national administrative traditions,' have influenced the implementation processes of international directives in each state (Linos, 2003, p. 12). Similarly, the styles of existing national policies can challenge compliance with international recommendations (Haverland, 2000). This can mean that states tend to do business as usual based on their existing structures, requiring strong leadership to affect a policy shift in government (Putman, 1998; Stiles and Thayne, 2006). This issue will be dealt with separately below by means of a theory of actors within states. Additionally, government resources required for processes such as policy design, implementation, monitoring and evaluation can also work as constraints on compliance. For instance, the relatively small size of Ireland's public sector hindered its ability to implement EU policies due to its limited budget (Mbaye, 2001, p. 261). In other words, a state's compliance depends on the government's management capabilities for associated resources, such as staff time, political energy and costs (Haas, 2008; Stiles and Thayne, 2006). Furthermore, behavioural change involves having access to a sufficient transition period for countries to be capable of inducing compliance (Chayes and Chayes, 1993).

The evidence above suggests a high correlation between the structural variables of the government and its administrative capability. In other words, factors which contribute to noncompliance can be found in the number of institutional actors engaged. It can be argued that difficulties in the policy implementation process tend to escalate as the number of actors increases (Mbaye, 2001). Fragmented institutional structures tend to problematise implementation (Haverland, 2010), and so it is important to have centralised control from within the central government. At the same time, a large number of actors can also result in failure to achieve a consolidated political will. It is equally critical that coalition partners in the governmental structure achieve political consensus; otherwise, the implementation process can be delayed (Linos, 2003). Thus, if the government's political system is polarised as opposed to fragment; this may also negatively influence the degree of compliance (Fang and Stone, 2012). In line with the fragmented structure of domestic institutions, actors with legislative powers 
can become another proxy for compliance. Domestic institutional veto players can prove to be persistent obstacles in the implementation process (Harverland, 2010; Linos, 2003). It is likely that implementation can be delayed due to key veto points in the government system, particularly when members are not interested or did not play critical roles in the negotiating process (Linos, 2003). These 'powerful minorities' in each institution can influence the necessary changes for compliance, and vice versa, especially when they are considering the compatibility of domestic laws and international laws (Putnam, 1988). At the same time, not only institutional actors, but also individual leaders can play a critical role in policy decisionmaking activities (Haas, 2008; Mbaye, 2001; Putnam, 1988). In addition, actors from the public are equally important in the policy choices and implementation process (Mbaye, 2001).

\section{Methodology}

The major determining variables in terms of compliance levels can be understood as the state choice and state capability, their actors at the national level, as well as the design of the norms at the international level. Among these, the three factors at the national level are interrelated. For instance, actors within states, represented by institutional actors in the aid management system, tend to be closely connected to both state choice and state capability theory in terms of the efficiency of the bureaucracy and the issue of political will. The literature review above has revealed that the number of actors engaged matters in terms of assessing the efficiency of the bureaucracy for behavioural change, which in turn is related to state capability. Not only that, the role of the dominant power's political arrangement amongst institutions is relevant in all three theories of compliance at the national level. It seems that establishing a consolidated domestic political will is critical when grasping the gap between a government's interests and global norms. With this in mind, this study offers two propositions: firstly, fragmented institutional structures can limit a government's bureaucratic efficiency in behavioural change for soft law abidance; and secondly, the lack of interest in change on the part of the dominant institution can be critical in the failure to establish a consolidated political will to implement global norms through national policies. As such, this study looks at domestic factors rather than systematic elements of soft law and organisational characteristics of international bodies. In line with these objectives, the following section will explore the general phenomena of OECD DAC membership in line with OECD principles and DAC peer review by examining each proposition. The study will then examine whether the propositions are consistent with the specific case of Korea, a non-European member country as well as a new DAC state.

In terms of research methods, this study deals with document analysis and participatory observation. Traditionally, participatory observation has been mostly used in ethnographic data collection, and is strongly related to observation of people's behaviour. According to Morris (as cited in Adler and Adler, 1998), participatory observation is defined as 'the act of noting a phenomenon, often with instruments, and recording it for scientific or other purposes'. In contrast to participatory observation, non-participatory observation 'refrains from interventions in the field'; rather, it 'follows the flow of events' (Flick, 2002, p. 135). In this research, participatory observation was conducted in the Korea International Cooperation Agency (KOICA), where I undertook the role of in-house advisor for the Peer Review Aid Effectiveness Session. Non-participatory observation was also conducted at the Ministry of Strategy and Finance (MOSF) during the Peer Review Aid Effectiveness Session and at the Ministry of Foreign Affairs and Trade (MOFAT) during preparation sessions of the peer review. As qualitative approaches are much more unstructured than quantitative methods due to their 
open-ended nature (Punch, 2005), predetermined categories and classifications were not deployed during the observations. By conducting participant and non-participant observations from within the government system, the aim was to witness the phenomena of behavioural changes and interactions between related institutions.

\section{OECD Principles and Peer Review for Effective Development Cooperation}

The OECD DAC has played a dominant role in establishing global norms and standards related to development cooperation. Both member and recipient states have participated in debates relating to aid effectiveness and effective development cooperation through the High Level Forums of the OECD DAC in Rome (2003), Paris (2005), Accra (2008) and Busan (2011). In other words, the OECD has designed global standards, disseminated knowledge and assessed the progress of aid management systems in global governance (Mahon and McBride, 2009). For example, the five principles and thirteen indicators of the PD have been used as a landmark for aid policies, strategies, and practices across countries. These were developed to maximise aid effectiveness by focusing on aid delivery and management mechanisms as part of a wider aim of supporting the achievement of the Millennium Development Goals (MDGs). In comparison, the AAA suggested new modalities of aid activities such as triangular cooperation and south-south cooperation. In the AAA, the role of civil society organisations (CSOs) as well as transparency issues were emphasised, and the need for separate approaches for fragile states was also discussed (OECD, 2011a). Accordingly, commitments to the PD and the AAA have been constantly referred to in OECD DAC peer reviews as dominant standards and principles for effective development cooperation, including aid management systems (for example, OECD, 2010a).

According to the OECD, a peer review is an 'examination of one state's performance or practices in a particular area by other states' (OECD, 2007b, p. 2). OECD peer review is designed to 'improve the quality and effectiveness of development cooperation policies and systems' and to 'promote good development partnerships' to contribute to poverty reduction and sustainable development. In this process, OECD peer review intends to promote the collective behavioural change of partners in development cooperation by increasing the mutual accountability of member states, reviewing their performance, and promoting the learning and sharing of peer practices (OECD, 2012c, p. 2). Based on this methodology, OECD DAC has encouraged its member states to implement OECD principles and indicators relating to development cooperation to different constituencies throughout the peer review process.

The OECD DAC has five stages in its peer review process: preparation and planning of the review; fact-finding, analysis and report writing; the peer review meeting; approval, publication, and launch of the peer review; and follow-up (OECD, 2012c). The OECD DAC peer reviews are conducted once every four to five years for each member country, and the 'mid-term reviews' are carried out between peer reviews. The mid-term review mechanism has been in practice since 2009 in order to monitor the performance of donors' behavioural changes in line with the peer review recommendations (OECD, 2012c). Apart from the peer reviews, the OECD DAC has also conducted 'special reviews' for non-DAC donor countries upon request in order to strengthen or reform their development cooperation structures by using the methodology of peer reviews (for instance, OECD, 2011b, 2011c). Based on half a century of experience of donor peer reviews, the OECD DAC has developed and provided best practices in donor performance for effective aid delivery and results, and has also reviewed the challenges for donors in implementing OECD DAC principles and standards. This section, 
therefore, examines whether these OECD DAC experiences are commensurate with the two propositions proposed in the previous section.

Based on the lessons learned through peer reviews across several countries, the OECD DAC has found that the institutional structures of aid management, or aid management systems, vary among members (see Figure 1) at the national level. As such, it has been suggested that member states decrease the number of institutional actors involved in development activities at the headquarter level and decentralise operational authorities at the field level. It has been revealed that such institutional reforms to integrated national development cooperation systems can enhance the effectiveness of international aid (OECD, 2008c).

FIGURE 1. OECD Categorisation of Aid Management Systems

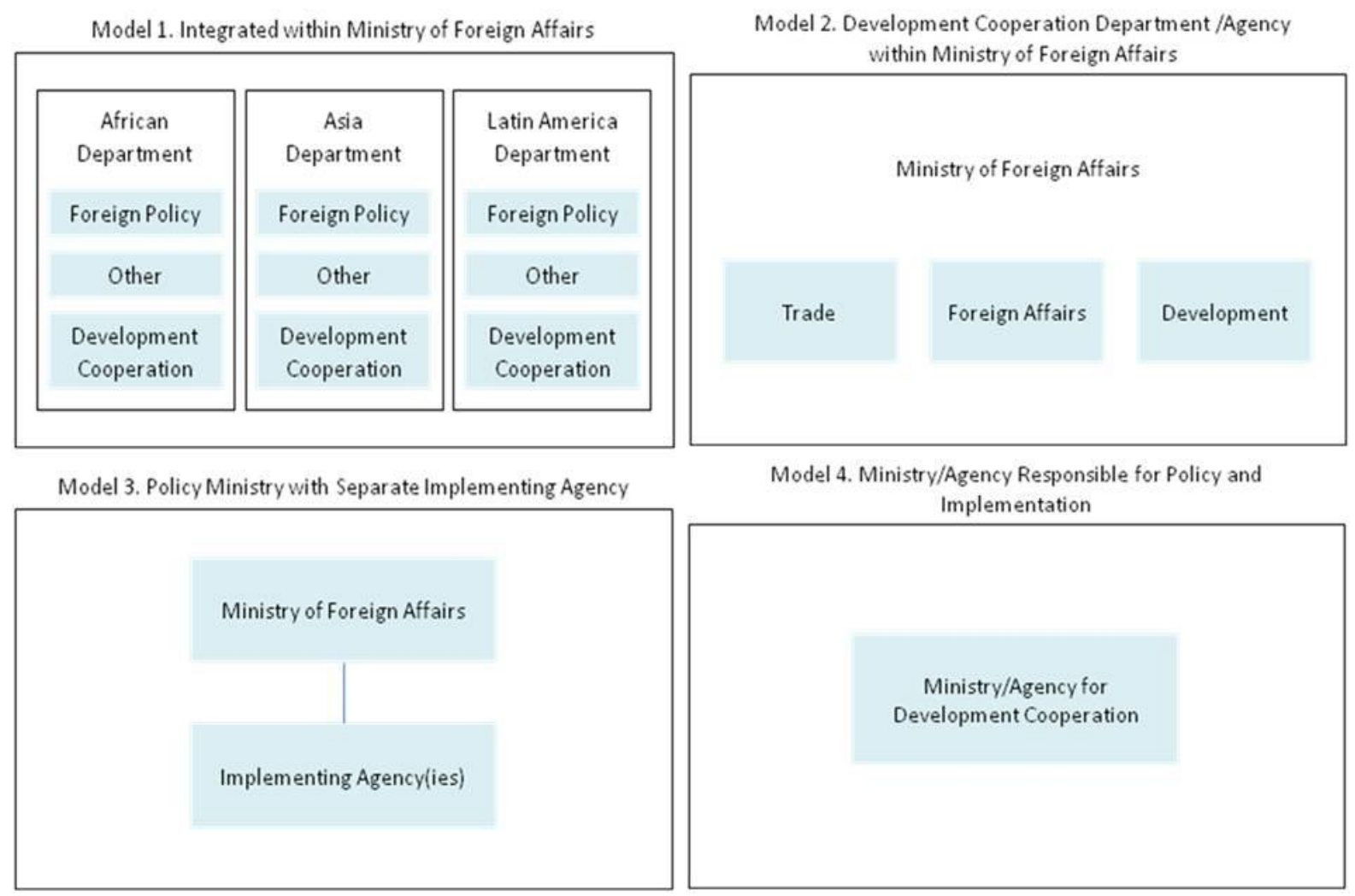

Source: Adapted from OECD 2009, p. 31

The OECD encourages DAC members to have one consolidated body responsible for implementing aid management, whether this is the ministry of foreign affairs or a separate ministry for development. Based on continuous discussions through peer pressure and learning processes throughout the peer reviews, countries such as Japan and Germany have restructured their institutional systems of development cooperation from a fragmented to consolidated form. Japan established the new Japanese International Cooperation Agency (JICA) in 2008 by merging key institutions into one agency in accordance with the peer review recommendations, as seen in Figure 2 (OECD, 2010b). Various aid organisations dealing with technical cooperation in Germany, including the Gesellschaft für Technische Zusammenarbeit (GTZ), the Internationale Weiterbildung und Entwicklung gGmbH (InWEnt) and the Deutscher Entwicklungsdienst (DED), were merged into the Gesellschaft für Internationale 
Zusammenarbe (GIZ) under the Federal Ministry for Economic Cooperation and Development (BMZ) in 2011. Germany too had been repeatedly criticised in its peer reviews for its inefficient bureaucracy due to its dispersed institutional system and limited organisational capacity for effective aid delivery (OECD, 2010b).

FIGURE 2. Japanese Institutional Integration Reform

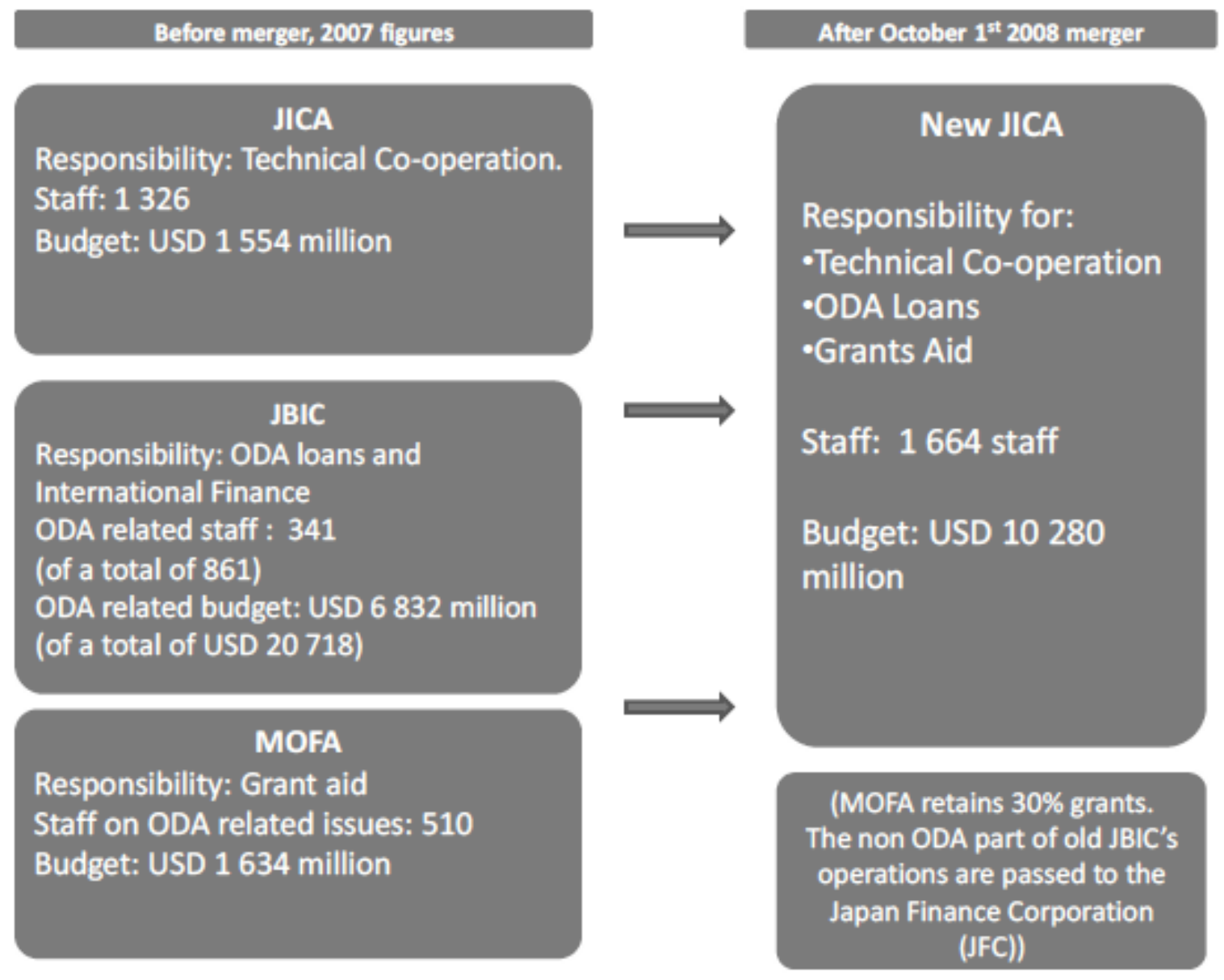

Source: Adapted from OECD 2010c, p. 54

The OECD has argued that identifying and appointing a senior figure at the highest level of the system or its administrative leadership structure is as important as consolidating multiple development institutions in order to enhance the effectiveness of aid delivery (OECD, 2008c). In this, the political will of the high-level bureaucrats is highlighted. For example, it has been constantly emphasised that political commitment by top-level statement of the development cooperation or a clear official statement at the political representation level can contribute to consolidating development cooperation policy in countries, on the basis of lessons learned from donor country experiences (OECD, 2008c, 2009).

According to the OECD, the effectiveness of the peer review methodology stems from international peer pressure directed at the national political level. While monitoring donor compliance with PD principles, it has been pointed out that lack of high-level support from officials and political leaders leads to insufficient behavioural changes in the implementation 
process (OECD, 2008a, 2009). This, in turn, can be interpreted as a result of the government seeking specific incentives and interests when deciding whether to adhere to the international principles (Molenaers and Nijs, 2011). As such, the OECD DAC has recommended countries to have a 'clear top-level statement' in order to effectively operate such a complex political environment at the national level (OECD, 2008c). For example, both Sweden and the UK expressed their political will to commit to the global aid effectiveness agenda and PD principles in their White Papers and aid bills and acts (for instance, see DFID, 2006; Sida, 2006). In contrast, the US implemented the PD requirements in a limited manner due to a lack of political will stemming from lack of interest amongst the dominant institutions dealing with development cooperation. Despite the government of the US being one of the signatories to the $\mathrm{PD}$, the PD requirements did not prevail over related agencies due to their separate interests (Bissio, 2007; Wood et al., 2008). The US Agency for International Development (USAID) paid little attention to the harmonisation principle of the PD, and the National Foreign Trade Council of the US intentionally stopped using the country procurement system (PD indicator 5b), on the basis of their own interests (Bissio, 2007; De Renzio, 2008; Martin, 2008).

\section{Peer Review and Behavioural Change in South Korea}

Korea obtained its DAC membership in late 2009, with membership status commencing officially from January 2010. Before joining the OECD DAC, Korea underwent a special review process in 2008 with examiners from Canada and Australia. In accordance with the recommendations provided, the Korean government made some minor changes in order to enhance its aid management system according to OECD DAC requirements. However, the changes have not been significantly realised, partially because the Korean government had only a three-year period to implement changes between 2008 (when the special review results were published) and 2010 (when Korea commenced the DAC membership). Compared to the Korean case, Japan spent around five years to change its aid management system. As Figure 2 shows, Japan conducted a merger of key aid management institutions into one agency in 2008 on the basis of the recommendations provided in the 2003 peer review (see OECD, 2003).

Even though Korea made few changes to its aid management system, it obtained OECD DAC membership. The first peer review was conducted in June 2012 by Australia and Germany. The peer review results were then published in December 2012. According to new regulations introduced by the OECD DAC, Korea is now expected to have a mid-term review in 2015 and another peer review within 2017. Korea has, therefore, followed the OECD DAC requirements for aid and development cooperation (PMO, 2012). However, the system of management in Korea has been different to that of other OECD DAC member countries. Prior to the special review of 2008, the institutional structure of Korea's aid management was polarised, consisting of two governing ministries and two operational agencies. In terms of bilateral aid distribution, MOFAT and the MOSF were the main governing bodies. MOFAT has been primarily responsible for managing grants through KOICA whilst the MOSF has been in charge of overseeing loans through the Economic Development Cooperation Fund (EDCF) managed by the Export-Import Bank (Exim Bank). Grant-type aid has been mainly administered by KOICA, which pursues integrated development including economic, social and sustainable development. Loan-type aid has been provided by Exim Bank, including the EDCF, which is aimed at fostering mutual economic cooperation. However, following the introduction by the MOSF of its Knowledge Sharing Programme (KSP) as a form of technical cooperation based on grants, MOFAT is no longer the sole agency responsible for grants. On the other hand, when dealing with contributions through multilateral channels, MOFAT has 
assumed the role of designated official agency to the UN system whereas the MOSF has performed a similar function with regards to multilateral development banks, such as the World Bank, the Asian Development Bank and the African Development Bank. Moreover, the Bank of Korea dealt with the subscriptions and loans under the MOSF's supervision (Office for Government Policy Coordination of the Republic of Korea, 2005). Based on this institutional arrangement, MOFAT and the MOSF had thereby worked separately and independently without any superior governing body. Figure 3 demonstrates the former structure of the Korean aid management institutions.

FIGURE 3. Aid Management Institutional Structure in South Korea before 2006

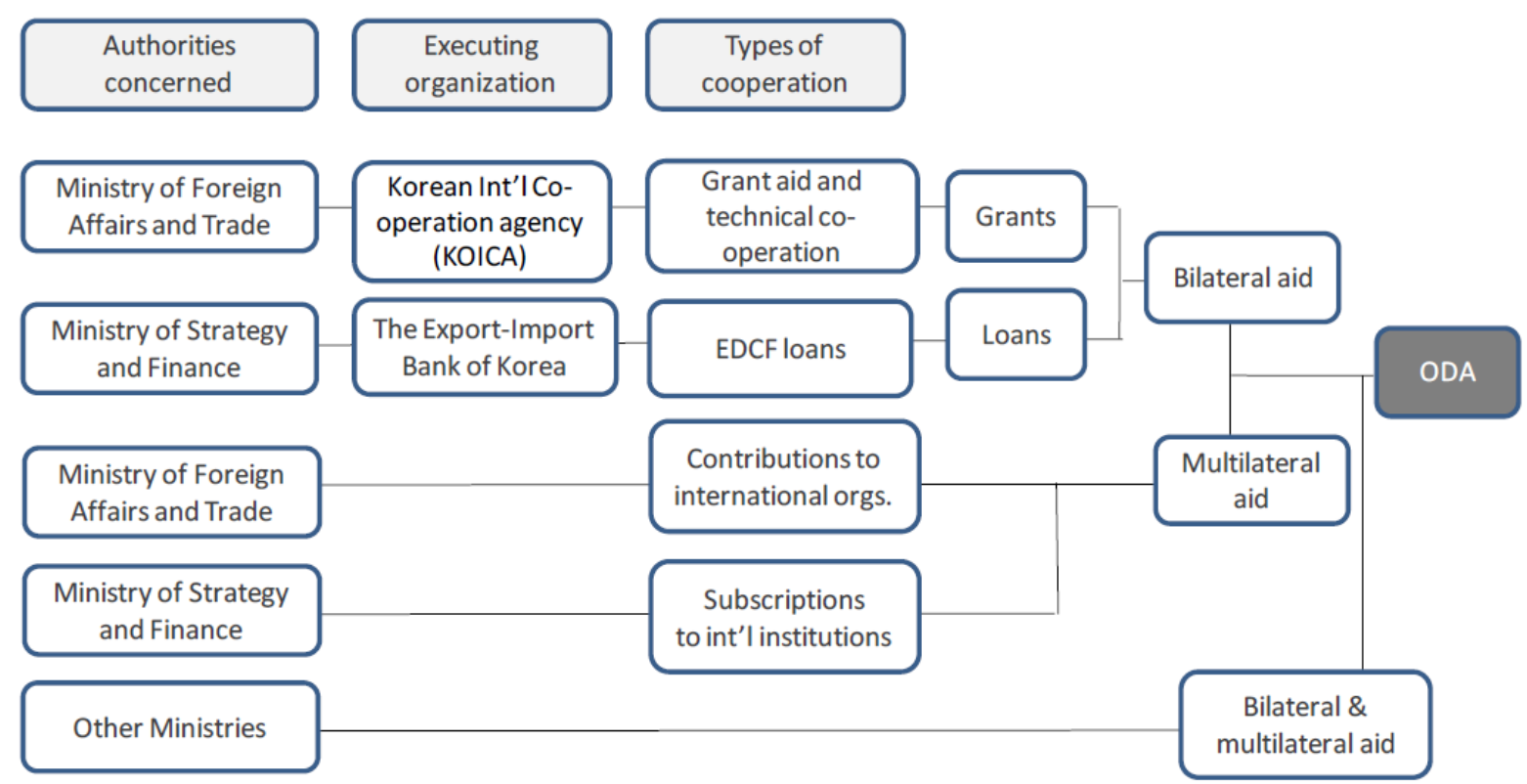

Source: Adapted from OECD 2008b, p. 10

In 2005, however, the Overall Policy Improvement Framework of the Korean government proposed the International Aid Act. This Act regulates the official development aid (ODA) scheme including the establishment of relevant bodies, grants, loans and policies. A year later, in line with the measures of the Committee for International Aid Policy, the Committee on International Development Cooperation (CIDC) was established. Currently, the CIDC consists of staff members from relevant ministries, including MOFAT and the MOSF, along with experts who were appointed from outside the government system (PMO, 2012). According to the Korean government, the CIDC was initially planned to consolidate all aid management institutions in the country by dealing with aid policies and strategies, aid system improvement, annual, mid-term and long-term plans, and operation (Office for Government Policy Coordination of the Republic of Korea, 2005). Nevertheless, when Korea underwent its special review in 2008, the OECD DAC recommended creating a 'less fragmented aid system with more unified strategies' (OECD, 2008b, p. 22), and as a result, the process of change for an advanced model of aid management was presented by the Korean government during the peer review in 2012, as shown in Figure 4. 


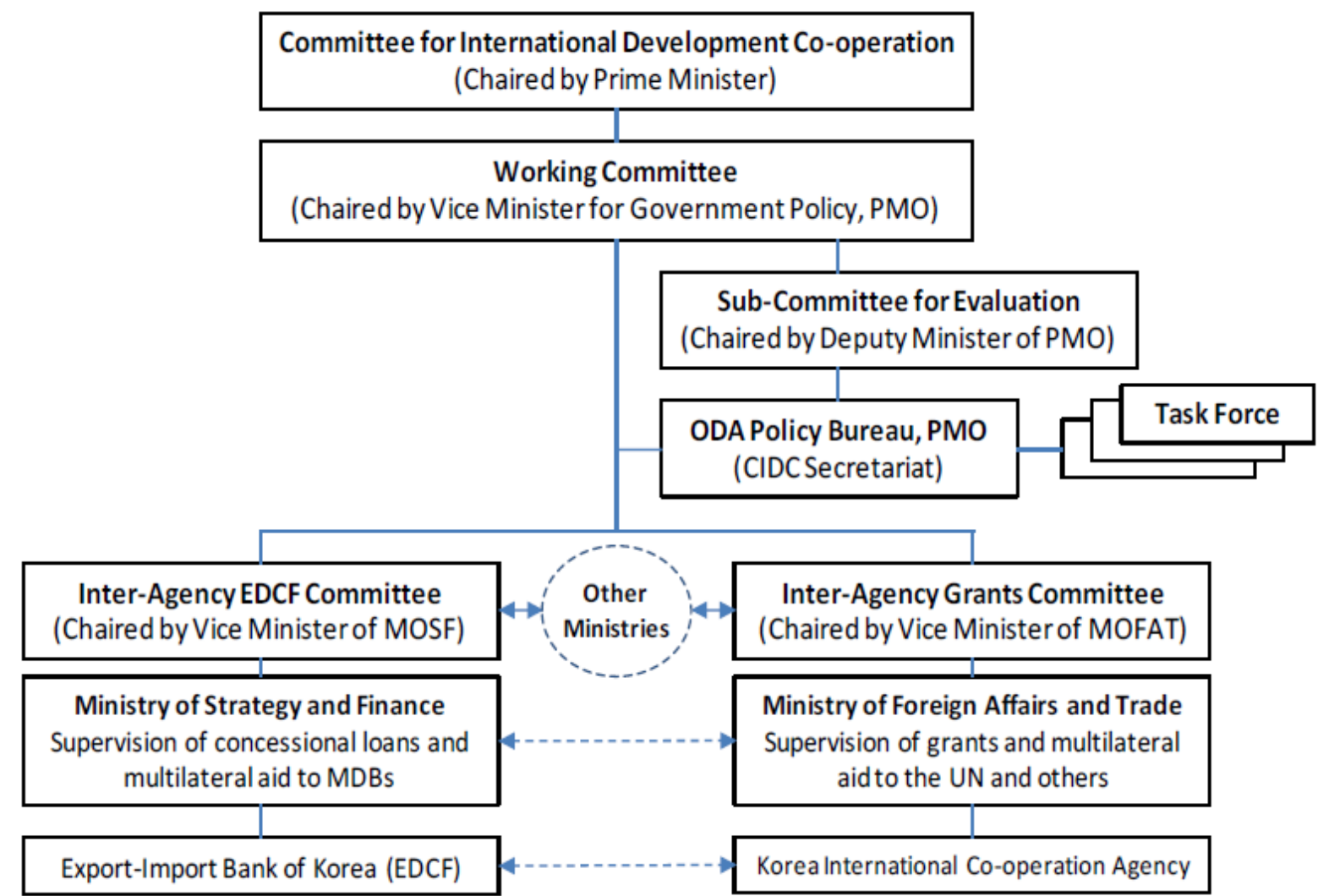

Source: Adapted from OECD 2012a, p. 63

Nonetheless, the peer review recommendations on institutional structure in Korea's aid management system remain unimplemented in the years between the 2008 special review and the 2012 peer review, and the number of government ministries and agencies involved in aid activities remained the same, at over 30 organisations (OECD, 2008b, p. 1, 2012a, p. 17). As a result, the OECD DAC constantly emphasised the importance of policy coherence amongst fragmented institutions. However, in spite of efforts towards policy coherence, the final peer review report demonstrates that Korea still needs to 'build on the solid legal and policy foundations' (OECD, 2012a, p. 34), and 'enhance policy coherence for development' through the leadership of the CIDC and the Prime Minister's Office (PMO) (OECD, 2012, p. 43). This recommendation differed little from the 2008 special review recommendation relating to the need for 'a single entity with sole authority over development cooperation objectives, policy and strategy, which can develop a united policy framework, which leads and applies to all parts of the ODA system' (OECD, 2008b, p. 12).

Furthermore, the need to strengthen the leadership roles of the PMO and CIDC were again highlighted (OECD, 2012a), suggesting that the CIDC did not properly play its directive role with regards to Korea's aid management system by the time of special review. During the peer review sessions as well as the review for the subsequent peer review report, more than eight ministries and agencies gave their inputs into the revision (The Government of Korea, 2012). This signifies the continued culture of division in Korea's aid institutions, resulting in the slow implementation of peer review recommendations. As such, between 2008 and 2012, there has been little substantive change in the nature of Korea's aid management system despite the constant pressure from the OECD DAC and other peer member countries. 
As noted above, the OECD DAC has persuaded its members to establish clear public political statements, such as White Papers, which demonstrate the will to comply with international norms through the national policies. However, when the first peer review was carried out, Korea still lacked clear policy documents on development cooperation, and major government policy papers tend to remain classified (OECD, 2012a). As a result, both special review and peer review reports have repeatedly stated the importance of a leadership body which can lead the process of implementation of OECD DAC recommendations. However, it turns out that neither the CIDC nor the PMO have the requisite leadership capacity to carry out legislative changes enabling the implementation of DAC standards. Instead, the MOSF has shown a strong tendency towards exercising its budget veto power as a means of increasing its bargaining power vis-a-vis other ministries. As noted in the peer review report, projects and programmes approved by the Inter-Agency Committees and endorsed by the CIDC have been rejected by the MOSF on the basis of its own specific approval criteria (OECD, 2012a), as shown in Figure 5.

FIGURE 5. Aid Planning and Budgeting Process in Korea, as of 2012

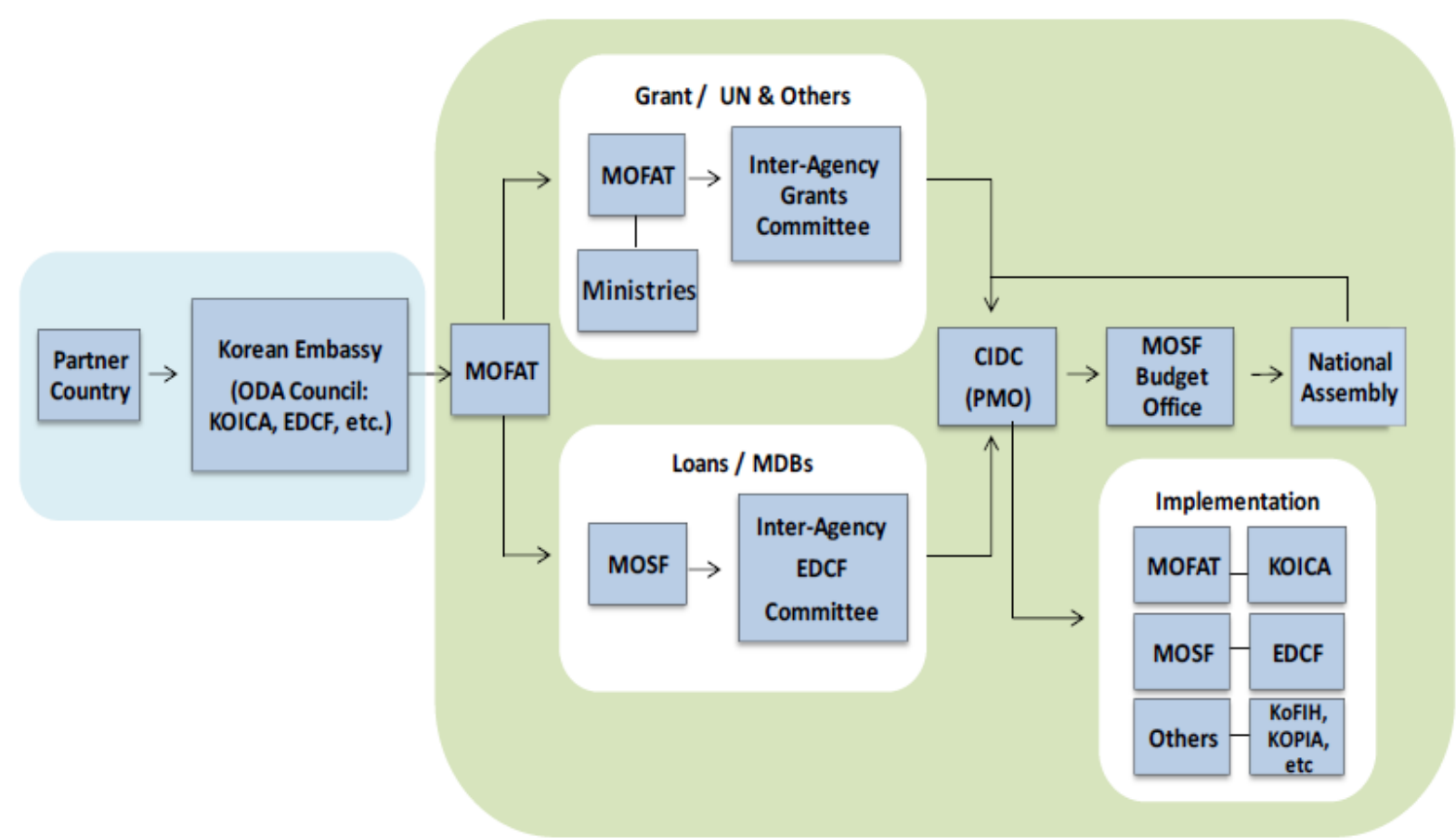

Source: Adapted from OECD 2012a, p. 48

Furthermore, during the fourth stage of the OECD DAC peer review process, it transpired that the MOSF was strongly opposed to recommendations concerning levels of ODA. Initially, in the document prepared on 20 November 2012, recommendation article 3.1 was stated as:

Korea should increase the ratio of grants to loans for fragile states and highly-indebted poor countries (HIPCs) and consider phasing out loans to these countries over time to ensure debt sustainability (OECD, 2012d, p. 5). 
However, the article has now changed to the following:

Korea should assess carefully the ratio of grants to loans for fragile states and highlyindebted poor countries (HIPCs) and when extending loans consider carefully the economic context and financial governance of these countries to ensure debt sustainability (OECD, 2012e, p. 5).

As mentioned above, the MOSF takes primary responsibility for the disbursement of loans, and thus, does not agree to any reduction in the proportion of loans in Korea's total ODA. As such, the MOSF's political interests within the broader governmental system have become obstacles to behavioural change towards OECD DAC regulations. The MOSF's interests are, furthermore, inconsistent with the OECD DAC Recommendation on Terms and Conditions of Aid, which requires donors to include least developed countries (LDCs) within their portfolios. Following the special review, Korea has also been under pressure to integrate grants and concessional loans (see OECD, 2008b, p. 18), whereas the MOSF continues to maintain or even increase the polarisation of aid types. Since the peer review results were published, the MOSF-controlled Exim Bank of Korea has argued that Korea no longer needs to comply with the DAC standards but rather needs to 'overcome its complex' and adopt a 'differentiated aid system and mechanism based on Korea's unique circumstances.' Indeed, the DAC peer review examiners concluded that Korea has a 'relatively consolidated ODA system compared to other DAC members' (see Korea Exim Bank 2013, pp. 1-3). These narratives demonstrate the degree to which a dominant institution such as the MOSF's has little interest in the implementation of DAC principles. This lack of interest has prevented the emergence of the consolidated political will necessary to adopt and implement global norms relating to development cooperation within Korea.

\section{Concluding Remarks}

This study has examined the reasons why member states vary in terms of their implementation of OECD DAC directives. Given the overwhelmingly European focus of the existing literature on compliance, the study established two propositions relevant to nonEuropean cases. As such, the article has examined the case of Korea, a new member state of the OECD DAC system and has suggested that the compliance of DAC member states are not that much different from cases of the compliance of European countries with other international laws. The Korean case shows consistency in terms of the propositions drawn by the theories. First, the fragmented institutional structure and lack of strong directive capacity in Korea limits ability to comply as a result of the government's bureaucratic inefficiency, as in most of the OECD DAC member states. The article also demonstrates that the domestic institutional structure has a strong relation to bureaucratic capacity for compliance. Second, the lack of interest on the part of the legislative powers at the domestic level has been a critical obstacle for establishing a consolidated national political will for compliance. Not only in Korea, but also in most of the member states, the lack of political will at the highest levels of the government hierarchy as well as the divergent political interests of the leading institutions have led to a lack of behavioural change towards the implementation of international principles and norms. Especially in Korea, it is significant that the development cooperation system evolved on the basis of the experiences, trends and culture of the governmental system.

The implications of this study are that the special review and peer review mechanism can be an effective methodology for new DAC donors to identify the barriers to change. In the 
Korean case, it is evident that the special review and peer review as well as the onset of DAC membership more broadly have improved the domestic conceptualisation of international norms across ministries and agencies. However, Korea's aid management system only can be transformed once it achieves a consolidated national political consensus amongst institutions. As such, the findings of this article illustrate that challenges such as a negative influence of a dichotomous institutional structure may slowly wither away as a result of continuous pressure and persuasion and peer countries but also by the domestic political processes. With this in mind, future DAC candidates can benefit from the lessons learned from the Korean case: to adopt and conform to the global principles and standards of development cooperation mechanism only when they are in ready for restructuring their aid management systems, including institutional arrangements, before commencing the membership with a consolidated political will to change at the domestic level.

\section{References}

Abbott, K. and D. Snidal (2000). Hard and Soft Law in International Governance. International Organization, 54(3), pp. 421-456.

Adler, P. A. and P. Adler (1998). Observational Techniques. Collecting and Interpreting Qualitative Materials. In N. K. Denzin and, Y. S. Lincoln (Eds.), Collecting and Interpreting Qualitative Materials (pp. 79-109). London: SAGE Publications.

Börzel, T. A., T. Hofmann, D. Panke and C. Sprungk (2010). Obstinate and Inefficient: Why Member States Do not Comply with European Law. Comparative Political Studies, 43(11), pp. 1363-1390.

Bissio, R. (2007). Application of the Criteria for Periodic Evaluation of Global Development Partnerships - as Defined in Millennium Development Goal 8 - from the Right to Development Perspective: the Paris Declaration on Aid Effectiveness. A/HRC/8/WG.2/TF/CRP.7. 31 December 2007. United Nations Human Rights Council.

Chayes, A. and A. H. Chayes (1993). On Compliance. International Organization, 47(2), pp. 175-205.

De Renzio, P. (2008). Practical Challenges for Delivering on Paris: A Political Economy Perspective. Presentation presented at the ODI Seminar. April, London.

DFID (Department for International Development) (2006). DFID's Medium Term Action Plan on Aid Effectiveness: Our Response to the Paris Declaration. Donor Policy and Partnerships Team, Policy Division.

Donno, D. (2010). Who Is Punished? Regional Intergovernmental Organisations and the Enforcement of Democratic Norms. International Organization, 64(Fall), pp. 593-625.

Fang, S. and R. W. Stone (2012). International Organisations as Policy Advisors. International Organization, 66(4), pp. 537-569.

Glodmann, M. (2012). We Need to Cut Off the Head of the King: Past, Present, and Future Approaches to International Soft Law. Leiden Journal of International Law, 25, pp. 335368.

Haas, P. M. (2008). Compliance with EU Directives: Insights from International Relations and Comparative Politics. Journal of European Public Policy, 5(1), pp. 17-37.

Holzinger, K., C. Knill and T. Sommerer (2008). Environmental Policy Convergence: The Impact of International Harmonisation, Transnational Communication, and Regulatory Competition. International Organization, 62(Fall), pp. 553-587. 
Kim, S. and S. Lightfoot (2011). Does 'DAC-Ability' Really Matter? The Emergence of NonDAC Donors: Introduction to Policy Arena. Journal of International Development, 23, pp. 711-721.

KOICA (Korea International Cooperation Agency) (2008). Paris Declaration Implementation Monitoring Survey Guidelines. January 2008. Unpublished manuscript, KOICA, Seongnam-Si.

KOICA (2011). Paris Declaration Implementation Monitoring Survey Guidelines. February 2011. Policy Planning Team. Unpublished manuscript. Seongnam-Si: KOICA.

Korea Exim Bank (2013). The Main Issues and Interpretation of the OECD DAC Peer Review. EDCF Issue Paper Vol. 2 No. 1. Seoul: Korea Exim Bank.

Linos, K. (2003). How Can International Organisations Shape National Welfare States? Evidence from Compliance with EU Directives. Working Paper No. 107 (Cambridge, Mass: Centre for European Studies, Harvard University).

Mahon, R. and S. McBride (2009). Standardising and Disseminating Knowledge: the Role of the OECD in Global Governance. European Political Science Review, 1(1), pp. 83-101.

Martin, M. (2008). Delivering beyond Paris: Objectives for Accra. Presentation presented at the ODI Seminar. April, London.

Mbaye, H. A. D. (2001). Why National States Comply with Supranational Law: Explaining Implementation Infringements in the European Union, 1972-1993. European Union Politics, 2(3), pp. 259-281.

Molenaers, N. and L. Nijs (2011). Why the European Commission Fails to Adhere to the Principles of Good Donorship: The Case of the Governance Incentive Tranche. European Journal of Development Research, 23(3), pp. 409-425.

OECD (Organisation for Economic Co-operation and Development) (2003). DAC Peer Review: Japan. Paris: OECD.

OECD (2007a). Aid Effectiveness: 2006 Survey on Monitoring the Paris Declaration,

Overview of the Results. OECD Journal on Development, 8(2), pp. 1-130.

OECD (2008a). Aid Effectiveness: A Progress Report on Implementing the Paris Declaration. Paris: OECD.

OECD (2008b). Development Cooperation of the Republic of Korea: DAC Special Review. Paris: OECD.

OECD (2008c). Effective Aid Management: Twelve Lessons from DAC Peer Reviews. Paris: OECD.

OECD (2009). Managing Aid: Practice of DAC Member Countries. Paris: OECD

OECD (2010a). DAC Peer Review Content Guide. DCD/DAC(2010)33/FINAL. Paris: OECD.

OECD (2010b). DAC Peer Review: Germany. Paris: OECD

OECD (2010c). DAC Peer Review: Japan. Paris: OECD.

OECD (2011a). Aid Effectiveness 2005-10: Progress in Implementing the Paris Declaration. Paris: OECD.

OECD (2011d). DAC Special Review of Poland. Paris: OECD.

OECD (2011c). Special Review of Slovenia. Paris: OECD.

OECD (2012a). DAC Peer Review: Korea. Paris: OECD.

OECD (2012c). Information Note on the DAC Peer Review Process. DCD(2012)4. Paris: OECD.

OECD (2012d). Review of the Development Cooperation Policies and Programs of Korea: DAC's Main Findings and Recommendations (Note by the Secretariat). 20-Nov-2012. DCD/DAC/AR(2012)2/26/PART1. Paris: OECD. 
OECD (2012e). Review of the Development Cooperation Policies and Programs of Korea: DAC's Main Findings and Recommendations (Note by the Secretariat). 21-DEC-2012. DCD/DAC/AR(2012)2/26/PART1/FINAL. Paris: OECD.

Office for Government Policy Coordination of the Republic of Korea (2005). Overall Policy Improvement Framework.

Pagani, F. (2002). Peer Review as a Tool for Cooperation and Change. African Security Review, 11(4), pp. 15-24.

Paulo, S. and H. Reisen (2010). Eastern Donors and Western Soft Law: Towards a DAC Donor Peer Review of China and India? Development Policy Review, 28(5), pp. 535-552.

PMO (Prime Minister's Office of the Republic of Korea) (2012). Structure. Published in 2012. Retrieved 30 January 2013, from http://www.odakorea.go.kr/index.jsp.

Punch, K. F. (2005). Introduction to Social Research (2nd edition). London: SAGE Publications.

Putnam, R. D. (1988). Diplomacy and Domestic Politics: the Logic of Two-Level Games. International Organization, 42(3), pp. 427-460.

Rolands, D. (2008). Emerging Donors in International Development Assistance: A Synthesis Report. PBDD.

Schäfer, A. (2006). Resolving Deadlock: Why International Organisations Introduce Soft Law. European Law Journal, 12(2), pp. 194-208.

Sida (Swedish International Development Cooperation Agency) (2006). Increased Aid Effectiveness: Sida Action Plan 2006-2008. POM Working Paper 2006: 2. Department for Policy and Methodology. Stockholm: Sida.

Skjaerseth, J. B., O. S. Stokke and J. Wettestad (2006). Soft Law, Hard Law, and Effective Implementation of International Environmental Norms. Global Environmental Politics, 6(3), pp. 104-120.

Tallberg, J. (2002). Paths to Compliance: Enforcement, Management, and the European Union. International Organization, 56(3), pp. 609-643.

Tarp, F. (Ed.). (2000). Foreign Aid and Development: Lessons Learnt and Directions for the Future. London: Routledge.

The Government of Korea. (2012). Review of OECD DAC Peer Review Report. Unpublished manuscript. Seoul: Government of Korea.

Trubek, D. M. and L. G. Trubek (2005). Hard and Soft Law in the Construction of Social Europe: the Role of the Open Method of Coordination. European Law Journal, 11(3), pp. 343-364.

UNECA (UN Economic Commission for Africa) (2002). The African Peer Review Mechanism: Process and Procedures. African Security Review, 11(4), pp. 6-13.

Wood, B., D. Kabell, N. Muwanga and F. Sagasti (2008_. Synthesis Report on the First Phase of the Evaluation of the Implementation of the Paris Declaration. Copenhagen: Ministry of Foreign Affairs of Denmark. 